\title{
Postmethod Pedagogy in Teaching English as a Foreign Language: Students' Perceptions
}

Rajan Kumar Kandel

\begin{abstract}
The study deals with the background context of postmethod pedagogy (PMP henceforth), a contextsensitive and critically practical pedagogy, differentiating it from the traditional concept of teaching by adhering strictly to a particular method of teaching a foreign language (the English language here) with reference to Nepal. It aims to explore the perception and inclination of M. Phil. pursuing students towards PMP in EFL teaching in Nepal. Google form of a questionnaire consisting of closed-ended items was used to collect data from 81 (of whom 65replied) M. Phil. pursuing (in English Education) scholars from Nepal Open University and Tribhuvan University. It revealed the gradual shift of ELT practitioners of Nepal from method-based instruction to PMP along with the intents of parameters of PMP, called pedagogy of particularity that advocates context-sensitivity in teaching and learning, pedagogy of practicality that insists for practicality and teacher-generated theories (theory of practice), and pedagogy of possibility that elicits the critical consciousness of the practitioners in terms of their socio-cultural context with adequate illustration. It was found that M. Phil. pursuing students had a positive attitude and supportive perception towards PMP leading to local and contextual superiority in pedagogy over the afforded methods although the local may be the hybrid of many foreign methods leading to an eclectic method.
\end{abstract}

Keywords: context-sensitivity, particularity, possibility, practicality

\section{Introduction}

Method is a plan for the orderly presentation of language skill and subject matter to be taught in the classroom. Richards and Rodgers define a method as "an overall plan for the orderly presentation of language materials, no parts of which contradicts and all of which is based upon the selected approach" (2005, p. 19). The method is the level at which theory is put into practice and at which choices are made about the particular skills to be taught and the content to be presented although what the teachers actually perform in the classroom differs from the theorists' advocacy (Kumaravadivelu, 2008). Nevertheless, a method is a route of teaching language in a systematic way. A method serves as a link between the theory and practice of language teaching. It is procedural in the sense that it tells us about the ways or procedures of language teaching in a systematic way. In this regard, Harmer (2007) states that a teacher can perform various roles to help the learners to learn language sometimes being democratic and sometimes being autocratic. Teaching language requires a method as a guideline for the teacher. The method may have been suggested by the researchers and theorists or it may have been discovered by the teacher him/herself out of his/her practice. The latter one is what suggested in post method pedagogy.

However, no easy and quick method is guaranteed to provide success because all language teaching methods assume that what teachers do in the classroom is already determinined (Brown, 2001, p. 15). 
This is because every learner is unique, every teacher is unique, and every learner and teacher relationship is unique wherever and whenever they exist. So, no perfect and ever suitable teaching method can be guaranteed to be used everywhere and for a long period of time. One method does not suit all due to many reasons. To run the teaching and learning activities smoothly, teachers need to be context-sensitive, innovative, and autonomous. In this regard, Kumaravadivlu (2008) advocates to fundamentally restructure our view of language teaching following one particular method tailored to be used in a particular context by certain methodologists guided by certain beliefs. Instead, he advocates for the emergence of PMP out of the multiple inflated images and myths of the methods, namely: there is the best method out there ready and waiting to be discovered; method constitutes the organizing principles for language teaching; method has a universal and ahistorical value; theorists can conceive knowledge, and teachers consume knowledge; method is neutral, and has no ideological motivation (2008, pp. 163-167) .

ELT practitioners in Nepal also ran head over heels without being critical to such misconceptions and the myths in support of the so-called methods for long. The methods suggested by the theorists were assumed as the universal ideological motivation equally applicable in our context. But at present, the practitioners have immensely realized the hegemony of the methods as a fox in tiger clothing. Very often they, are just white elephants because of not being able to address the practical contexts of the students, teachers, and educational institutions. They could not be equally applicable in our politico-economic context. So, the teachers, teacher trainers, and university graduates in the related field and in the ELT scenario of Nepal also aspire for the contextual method to be applied in their context. In many of the cases, we can observe that the teachers are even trying mixed-methods yielding into eclecticism. This depicts that the ELT practitioners in Nepal have also grown as the advocates of PMP. It is the matter of the fact that the post method is a new attempt in the era of methodology in our context. PMP emphasizes practical and contextual teaching through classroom context-sensitive activities. It deals with students and teachers that emphasizes situational socio-cultural, political and pedagogical context. In this line, the main objective of this study was to explore the perception, perspectives, opinions, and inclination of the M. Phil pursuing students from Nepal Open University and Tribhuvan University, Nepal towards the use of PMP in English language teaching in Nepal.

PMP does not mean that the practitioners should ignore the principles, assumptions, recommendations and procedures of established approaches, methods or theories (Kumaravadivelu, 2008). Rather, it suggests the practitioners adapt and innovate the best and the most appropriate method that is suitable for a specific context. Innovative practitioners in Nepal are also inclined to this line of thought at present.

\section{Postmethod Practitioners: Nepali Scenario}

In the EFL context of Nepal, the learners and the teachers have to be loyal to their socio-political, and cultural sensitivity. They should be encouraged not to lose their identities in the cost of learning (and teaching) English. Their native cultures, languages, identities, and social integrity should be mutually benefitted through L2 education. Teaching and learning of English should work as a catalyst for identity formation and social transformation (Kumaravadivelu, 2001) in Nepali context. The role of the education 
practitioners in Nepal is supposed to be revised and renewed in PMP out of the "monolithic matrix of methods" (Kumaravadivelu, 2001, p. 545) in the present socio-political era.

PMP seeks to make the learners autonomous to their learning. This is urgently required in Nepali context taking charge of their learning themselves unlike learning whatever is prescribed as better for them like in the traditional methods. PMP advocates for the wider view of learning rather than just learning to learn on the part of the learners. Learner autonomy is further specified as academic autonomy- learners being ready and able to take charge of their own learning to be effective learners, social autonomy- learners being ready to function cooperative members of a classroom community to be collaborative partners, and liberatory autonomy- learners being ready to recognize sociopolitical impediments (overt like political oppression or subtle like discrimination of any sorts) and raise voice against such impediments being critical thinkers (Kumaravadivelu, 2001). Such autonomous learners are the cry of the day in Nepal.

Similar to the learners, the post method pedagogy considers the teachers as autonomous. Postmethod teacher autonomy requires confident and competent teachers who "want to build and implement their own theory of practice that is responsive to the particularities of their educational contexts and receptive to the possibilities of their sociopolitical conditions" (Kumaravadivelu, 2001, p. 548). Postmethod teachers own the pluralistic view of methods. They choose from among many methods to create their own blend and use it in their practice instead of following only a method and its techniques as the rule of the thumb which is said to be an eclectic practice (Larshen-Freeman \& Anderson, 2011) or an eclectic method of teaching.

As suggested in PMP, Nepali English language teachers' prior knowledge as well as their potential to know not only how to teach English in Nepali context but also know how to act autonomously within the academic and administrative constraints imposed by institutions, curricula, and textbooks should be explored and brought into synergic praxis. The autonomy of Nepali English teachers and their praxis could promote their ability to know how to develop a reflective approach out of their own Nepali practice and how to analyze and evaluate their own teaching activities.

Traditionally, most models of teacher education are designed to spread a set of the preselected and pre-sequenced body of information from the teacher educator to the potential teachers. This is basically a top-down approach in which teacher educators convey their skills and knowledge to the trainee teachers (Kumaravadivelu, 2008). The task of post method teacher educator is to create a condition for potential teachers to acquire autonomy that enables them to reflect on and shape their own pedagogical experiences. The training to the teachers must be dialogic respecting the knowledge and experiences of the trainee teachers. To quote Kumaravadivelu, "A postmethod teacher education program must take into account the importance of recognizing teachers' voices and visions, the imperatives of developing their critical capabilities, and the prudence of achieving both of these through a dialogic construction of meaning" (2001, p. 552).

In Nepali context also such postmodern teacher educators who respect the feelings, experiences and understandings of the teachers are increasing in number. Many of them have realized that knowledge should be negotiated between the teachers and the students, and the teachers and the teacher educators. 
The educators should encourage the teachers to think critically and shape and reshape their knowledge out of their practices in collaboration with their learners. To support such pedagogical paradigms, it is an emerging task to explore the inclinations, perceptions, perspectives, and understanding of the M. Phil. pursuing students under the stream of education in the universities of Nepal because they are the potential teachers, teacher trainers, and ELT professionals at the policy, practice and further research levels.

\section{Review of Literature}

In reviewing the literature in this section, the conceptual and theoretical review of the literature has been discussed at first followed by the discussions and understandings of pedagogic parameters of PMP in ELT pedagogy in Nepal. Then, the studies in the area in Nepal have been reviewed indicating the gap in research justifying the need for this study.

The concept of the method is a century-old obsession (Brown, 2002). It cannot work equally forever with heterogeneous students throughout the globe. PMP has emerged to make the teaching of English free from any sorts of method based restrictions (Chen, 2014) celebrating the death of the methods. Method based pedagogy confines us to follow the directions prescribed. It "authorizes theorizers to centralize pedagogic decision-making" (Kumravadivelu, 2003, p. 32) but PMP lets us go elsewhere and overcome the restrictions of method-based pedagogy. PMP encourages practitioners to produce location-specific, classroom-oriented innovative practices.

Theory-neutral and method-neutral but not atheoretical and methodless macrostrategies like: maximize learning opportunities, minimize perceptual mismatches (between intention and interpretation of the learner, the teacher, and teacher educator), facilitate negotiated interaction, promote learner autonomy, foster language awareness, activate intuitive heuristic (provide rich textual data and let students infer and internalize rules), contextualize linguistic input, integrate language skills, ensure social relevance, and raise cultural consciousness (Kumravadivelu, 2003, pp. 39-40) are suggested to the practitioners to implement the PMP appropriately at their respective contexts. PMP seeks for democratic, critical, and emancipatory learning. It is democratic and autonomous both to the students and teachers. It is also related to the scienceresearch conception of teaching where the inexperienced teachers "gain experience, they can then modify and adapt these initial theories of teaching, moving toward the more interpretive views of teaching implicit in theory-philosophy conceptions"(Richards, 2002, p. 25).

Based on the arguments put forward above, eight main aspects of PMP following Scholl (2017, p. 99), can best summarize this short paper, viz. the parameter of particularity is the primary maxim, adherence to the parameter of practicality is moderate, the parameter of possibility is an aspect which is context-dependent, PMP is learner-centred, PMP defaults moderately toward an experimental strategy, PMP defaults moderately toward a cross-lingual strategy, PMP defaults to a central configuration on the implicit -explicit continuum, and communicative competence is a tenant of PMP.

PMP suggests for the localized and context-sensitive methods of teaching despite blind belief and practice of the long-discovered methods at the foreign land enforced by certain foreign ideological contexts. PMP is a three-dimensional (three-D) system comprising of three pedagogical parameters 
(Kumaravadivelu, 2001). These three pedagogic parameters, viz. pedagogy of particularity, pedagogy of practicality, and pedagogy of possibility are shortly described herewith as the constitutive features of post method pedagogy and their relevancy in English language teaching context in Nepal.

Particularity means the pedagogy has to be context-sensitive to the local linguistic, socio-cultural, and political context of the place where the teaching takes place. To illustrate it, Kumaravadivelu mentions that a post method pedagogy, "must be sensitive to a particular group of teachers teaching a particular group of learners pursuing a particular set of goals within a particular institutional context embedded in a particular socio-cultural milieu" (2001, p. 538). All the teaching approaches, principles, theories, and methods are highly abstract and very difficult to implement in all contexts. To enhance the learning activities in an easier way, the innovation in $\mathrm{L}_{2}$ teaching and learning constricted with a holistic interpretation of particular situations is known as a pedagogy of particularity. Thus, to address the particular issues of the particular situation an innovative set of procedures are discovered and used. We need to have situational understandings as well as local linguistic, socio-cultural and political particularities in our teachings.

Nepali pedagogy, like Nepali politics, is local. Local is always fresh, intimate, and hygienic (Phyak, 2011) either this be a product, food item or a pedagogy. The methods inherited from abroad (Kumaravadivelu, 2001), cannot be equally applicable in our context due to the diverse context and needs of our students, teachers, parents, teacher educators, educational institutions, and the concerned authorities. Thus, the pedagogic parameter of particularity (of the PMP) is one of the most important constitutive features of PMP in L2 education in Nepal since Nepal is a politically, socially, culturally, topographically, and linguistically diverse country. Even within Nepal, the only domestic method cannot be used equally well due to this heterogeneity, let alone the so-called imported methods.

Practicality mainly refers to the relationship between theory and practice. The theories must emerge from practice. The teachers are the real practitioners of teaching. So, the teaching methods must originate from the teachers' practice by enabling the teachers to construct their own theory of practice (Kumaravadivelu, 2001). Pedagogy of practicality includes teacher autonomy and teacher professional development with a principal focus on reflective teaching and action research. To justify about practicality parameter, Kumaravadivelu states:

The parameter of practicality, then, focuses on teachers' reflection and action, which are also based on their insights and intuition. Through prior and ongoing experience with learning and teaching, teachers gather an unexplained and sometimes unexplainable awareness of what constitutes good teaching. (2008, p. 173)

Practicality believes that no theory of practice is useful and useable unless it is practical. This is equally applicable in Nepali context because a lot of pedagogic practices, development models, economic, and political systems afforded from outside have either failed or turned impractical. Following pedagogy of practicality, it is the time for searching teacher-generated theories out of their practice in Nepal. Such theories developed by the teachers could be the nativized and local theories likely to be practiced in their respective birthplace/context.

Pedagogy of possibility of PMP following the works of the Brazilian educator Paulo Frere, and 
such other transformative critical thinkers, stresses the importance of acknowledging the students' and teachers' identity along with the broader social, economic, and political context in which they grow (Kumaravadivelu, 2008). It encourages learners to be free from the cultural imperialism of the second language. It is concerned with sociopolitical reality and individual identity of the participants and the practitioners of the PMP. In this regard, Kumaravadivelu (2001, p. 543) mentions:

In the process of sensitizing itself to the prevailing sociopolitical reality, a pedagogy of possibility is also concerned with individual identity. More than any other educational enterprise, language education provides its participants with challenges and opportunities for a continual quest for subjectivity and self-identity.

In this way, PMP leads the teachers and learners to encourage for contextual selection and academic, socio-political, and liberatory autonomy in teaching and learning.

Based on the above-mentioned theoretical perspectives and pedagogic parameters, many studies have been carried out in the field of second or foreign language pedagogy. Paudel (2018) carried out a phenomenological descriptive study taking the sample of 12 teachers from Pokhara to find out teachers' perception towards PMP and found out that the teachers own positive attitude and reported that no method could be imposed upon assuming it as universal, best, or natural. The study reported that the teachers were hopeful to implement self-generated context-sensitive method to fit in the context of the students. The West-generated methods in the monolingual context cannot work well in our multilingual and multicultural context. However, the study is confined to eliciting the in-depth opinion of in-service teachers. Studies carried out in Nepal along with this study have yet to discover the perceptions and perspectives of preservice teachers and teacher trainers towards PMP.

\section{Methodology}

The perception of students pursuing M. Phil. Degree under the Faculty of Education from Tribhuvan University and Nepal Open University (Who are the potential teachers and teacher trainers of the country being exposed to the exciting and innovative methods of teaching and learning including carrying out the researches), towards PMP has been depicted through the four philosophical perspectives, viz. ontology, epistemology, axiology, and methodology. Based on the ontological perspective, it was supposed that respondents' perceptions can be derived through closed-ended survey questions including the Likert Scale questions since reality is out there in the social world, can be obtained through trends, attitudes, or opinions (Creswell, 2014). The research was based on the positivist paradigm ontologically following a single reality. Epistemologically, the study aimed to collect their perceptions towards PMP (knowledge) from sense experiences, and demonstrable, objective facts collected first hand leading towards empirical epistemology (Kivunja \& Kuyini, 2017). To ensure the objectivity of the data, validity and reliability of the research instruments was measured while piloting the instruments. The axiology behind the study was guided by the four criteria of ethical conduct, namely, teleology- the theory of morality which ensures the meaningful outcome of the research that will satisfy as many people as possible yielding more benefits to them than harm, deontology- the understanding that it intends to benefit all as a whole, morality- the 
intrinsic moral values to be followed in the research, and fairness- being fair to all the research participants respecting their rights (Kivunja \& Kuyini, 2017). Methodologically, the study followed the quantitative method, through a cross-sectional survey of the participants at the field. The data were collected to test the hypothesis and deduce the result/finding out of the analysis and interpretation of the data. The deductive approach was used to verify the quantitatively collected data.

Quantitative and non-experimental survey research design was used making it a cross-sectional survey design where the data were collected at one point in time (Creswell, 2012). The data were collected from the respondents scattered throughout Nepal who were pursuing their M. Phil. from two renowned universities of Nepal called Tribhuvan University and Nepal Open University. Out of the students studying in the first semester of their M. Phil. Degree from Nepal Open University and Tribhuvan University under the English Education Stream, sixty-five of them who replied the Google form sent to them duly filled (out of eighty-one respondents selected conveniently to whom the questionnaire in the Google form was sent) were the sample of the study. The detailed description of the population demography of the sample is presented in Table 1.

The respondents were contacted personally through phone calls and email with the help of the records of the universities. The academic area to be explored through the study was the beliefs, opinions, perceptions, and perspectives of the M. Phil. pursuing students towards PMP.

The research was mainly based on the primary data collected through a set of Google form of a questionnaire (Attached in a separate file herewith) consisting of the opinion seeking closed-ended questions as the instrument for collecting data. It included of seven informative questions including their sex, age, academic qualification, the university from where they earned their Master's Degree, their teaching experience, institution they were currently teaching at, and their ICT competency besides their name and email address and four sets of different closed-ended research. Set A included five statements with 'Yes' or 'No' responses, Set B consisted of five-point Likert Scale type of items with 'Strongly Agree (5)' to 'Strongly Disagree (1)' options, Set C comprised of five items with 'Always', 'Often', 'Sometimes', 'Rarely', and 'Never'; and Set D consisted of five items to be reflected against any one of; 'Untrue for me (1)', 'Slightly untrue for me(2)', 'Neutral (3)', 'Slightly true for me (4)', or 'True for me (5)' alternatives. The researcher mailed the Google form along with necessary instructions to the respondents for completing (filling up) the Google form both through the mail and their cell numbers. The form was collected back in the mail inbox after they duly filled up them reflecting their opinions against the alternatives. Then, the collected data were codified to insert into the Statistical Package for Social Sciences (SPSS 23) software and then descriptive and inferential analysis were carried out to show the relationship among the variables in the study. Visual graphic representation and the tabulation of the result were made to make it more comprehensible and systematic to test the hypothesis and come to the conclusion. 
Table 1

Population Demography of the Sample

\begin{tabular}{|c|c|c|c|c|}
\hline S.N. & Indicators & & Frequency & Percent \\
\hline \multirow[t]{2}{*}{1.} & \multirow[t]{2}{*}{$\operatorname{Sex}$} & Female & 12 & 18.5 \\
\hline & & Male & 53 & 81.5 \\
\hline \multirow[t]{4}{*}{2.} & \multirow[t]{4}{*}{ Age (years) } & $25-30$ & 12 & 18.5 \\
\hline & & $31-35$ & 28 & 43.1 \\
\hline & & $36-40$ & 19 & 29.2 \\
\hline & & $\geq 41$ & 6 & 9.2 \\
\hline \multirow[t]{4}{*}{3.} & \multirow[t]{4}{*}{ Academic qualification } & M. Ed. & 51 & 78.5 \\
\hline & & M. A. & 7 & 10.8 \\
\hline & & Both & 5 & 7.7 \\
\hline & & Other & 2 & 3.1 \\
\hline \multirow[t]{3}{*}{4.} & \multirow{3}{*}{$\begin{array}{l}\text { Institution from where } \\
\text { Master's Degree is } \\
\text { earned }\end{array}$} & Tribhuvan University & 60 & 92.3 \\
\hline & & Other Universities of Nepal & 4 & 6.2 \\
\hline & & Universities abroad & 1 & 1.5 \\
\hline \multirow[t]{5}{*}{5.} & \multirow{5}{*}{$\begin{array}{l}\text { Teaching experience at } \\
\text { any level (years) }\end{array}$} & $\leq 5$ & 9 & 13.8 \\
\hline & & $6-10$ & 18 & 27.7 \\
\hline & & $11-15$ & 30 & 46.2 \\
\hline & & $16-20$ & 5 & 7.7 \\
\hline & & $\geq 21$ & 3 & 4.6 \\
\hline \multirow[t]{4}{*}{6.} & \multirow[t]{4}{*}{ Institution teaching at } & School & 20 & 30.8 \\
\hline & & College & 29 & 44.6 \\
\hline & & Both & 15 & 23.1 \\
\hline & & Other & 1 & 1.5 \\
\hline \multirow[t]{4}{*}{7.} & \multirow[t]{4}{*}{ ICT competency } & ICT illiterate & 1 & 1.5 \\
\hline & & ICT literate & 15 & 23.1 \\
\hline & & Basic ICT skill & 44 & 67.7 \\
\hline & & Advanced ICT skill & 5 & 7.7 \\
\hline
\end{tabular}

To ensure the validity and reliability of the research instrument the researcher piloted the questionnaire to ten of the students and reliability was calculated statistically using SPSS software. Further, the content validity, construct validity, and criterion-related validity of the items were measured in collaboration 
with the colleagues, instructors, and the expert. The items of the questionnaire in the Google form were revised on the basis of the piloting feedback obtained. To maintain ethical consideration, informed consent was granted by informing the participants about the study and the tools were administered only after the permission was granted from them. The information given by the respondents was kept anonymous and confidential.

\section{Results and Discussion}

The result obtained from the data has been presented and discussed as per four different sets of the questions comprising of five items each in a set as follows:

Five items asked to collect their perception regarding the activities they think that should take place in the classroom were replied as follows by the participants (from between two alternatives; yes and no):

Table 2

Respondents' Opinion Regarding the Basic Aspects of PMP

\begin{tabular}{|c|c|c|c|c|}
\hline S. N. & Item Statement & & Frequency & Percent \\
\hline 1. & $\begin{array}{l}\text { Students should be encouraged to take part in } \\
\text { contextual activities in the classroom. }\end{array}$ & Yes & 65 & 100.0 \\
\hline \multirow[t]{2}{*}{2.} & $\begin{array}{l}\text { I consider social and political issues while teaching } \\
\text { in the classroom that are related to students' }\end{array}$ & Yes & 57 & 87.7 \\
\hline & context. & No & 8 & 12.3 \\
\hline \multirow{2}{*}{3.} & I encourage learners through activities that interest & Yes & 64 & 98.5 \\
\hline & them. & No & 1 & 1.5 \\
\hline \multirow{2}{*}{4.} & I respect cultural and cross-cultural differences of & Yes & 63 & 96.9 \\
\hline & the students in the classroom. & No & 2 & 3.1 \\
\hline \multirow{2}{*}{5.} & I follow one particular method strictly while & Yes & 3 & 4.6 \\
\hline & teaching & No & 62 & 95.4 \\
\hline
\end{tabular}

Table 2 depicts that all the participants believed that students should be encouraged to take parts in the contextual activities in the classroom. So, most of them (87.7\%) considered socio-political issues related to the students while teaching but $12.3 \%$ of them viewed that they did not notice it. All most all (98.5\%) responded that they encouraged the students with the activities that interest their students. Most of them $(96.9 \%)$ reported that they respected cultural and cross-cultural differences of the students. Only $4.6 \%$ of the respondents said that they followed on a particular method strictly while teaching but rest of them (95.4\%) did not reflecting their implicit inclination in favor of PMP.

One of the questions asked to the respondents, for example, has been illustrated in figure 1: 


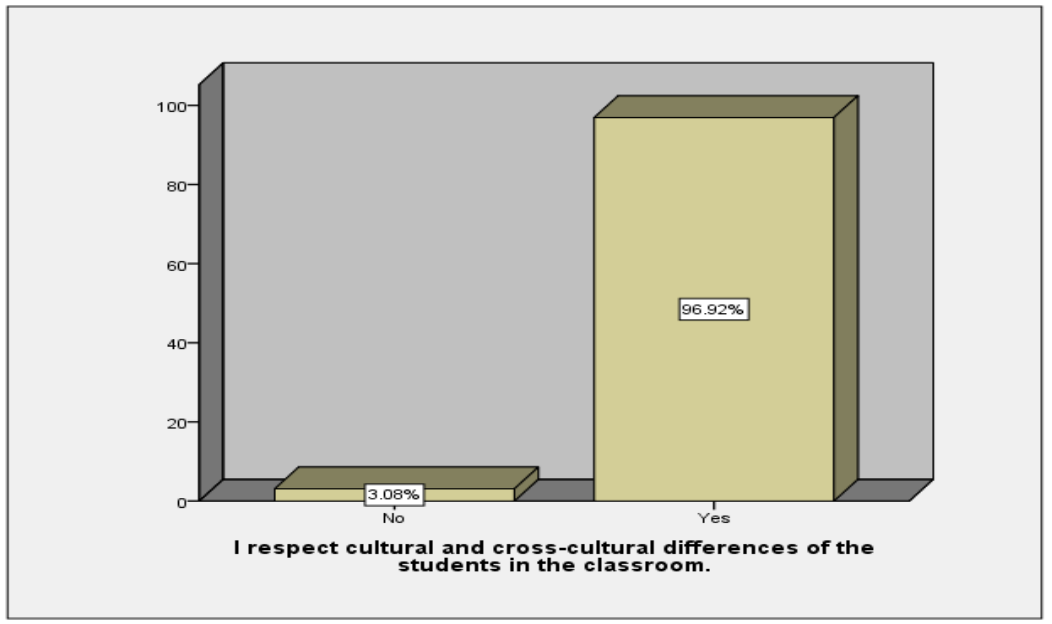

Figure 1. Respondents' response of respecting students' cultural differences. '

Figure 1 illustrates that a huge majority of the respondents respected cultural and cross-cultural differences of the students in the classroom while only $3.08 \%$ of them did not.

Five statement items to check against the five points Likert Scale from strongly disagree to strongly agree was included in set B. The statistics of the responses of the respondents displayed the following statistics as shown in table 3 .

Table 3

Statistic of the Respondents' Agreement Towards PMP

\begin{tabular}{|c|c|c|c|c|c|}
\hline Statistic & $\begin{array}{l}\text { 1. PMP } \\
\text { provides } \\
\text { autonomy to } \\
\text { the teachers } \\
\text { and students. }\end{array}$ & $\begin{array}{l}\text { 2. PMP } \\
\text { ignores other } \\
\text { methods of } \\
\text { teaching. }\end{array}$ & $\begin{array}{l}\text { 3. Teachers } \\
\text { should not } \\
\text { follow a certain } \\
\text { method in their } \\
\text { classes. }\end{array}$ & $\begin{array}{l}\text { 4. Teachers } \\
\text { should be } \\
\text { sensitive to socio- } \\
\text { politico-economic } \\
\text { and educational } \\
\text { environment. }\end{array}$ & $\begin{array}{l}5 . \text { Teachers } \\
\text { are resourceful } \\
\text { enough to } \\
\text { produce their } \\
\text { own teaching } \\
\text { methods. }\end{array}$ \\
\hline Valid & 65 & 65 & 65 & 65 & 65 \\
\hline Missing & 0 & 0 & 0 & 0 & 0 \\
\hline Mean & 4.062 & 2.262 & 3.723 & 4.431 & 4.062 \\
\hline Std. Deviation & 1.1974 & 1.3725 & 1.3751 & 1.1588 & 1.1302 \\
\hline Skewness & -1.249 & .706 & -.856 & -2.220 & -1.196 \\
\hline $\begin{array}{l}\text { Std. Error of } \\
\text { Skewness }\end{array}$ & .297 & .297 & .297 & .297 & .297 \\
\hline Kurtosis & .683 & -.801 & -.492 & 3.909 & .751 \\
\hline $\begin{array}{l}\text { Std. Error of } \\
\text { Kurtosis }\end{array}$ & .586 & .586 & .586 & .586 & .586 \\
\hline
\end{tabular}


Table 3 displays that the mean score of items number one, four and five is higher than four (which means agree). The respondents' agreement towards these items is inclined towards strongly agree from agree. So, they were (strongly) agreed that PMP provides autonomy to the teachers and students, teachers should be sensitive towards the social, political, economic and educational environment of the students, and teachers are resourceful enough to produce their own teaching methods. They were neutral but inclined towards agree $(\mathrm{M}=3.723)$ in the saying that teachers should not follow a certain method in their classes but they disagreed $(M=2.262)$ that PMP ignores other methods of teaching. Similarly, the standard deviations, skewness, Kurtosis are also not very high. This shows that the responses of the respondents were not very different.

To illustrate the responses, the histograms in figure 2 represent each of the items:
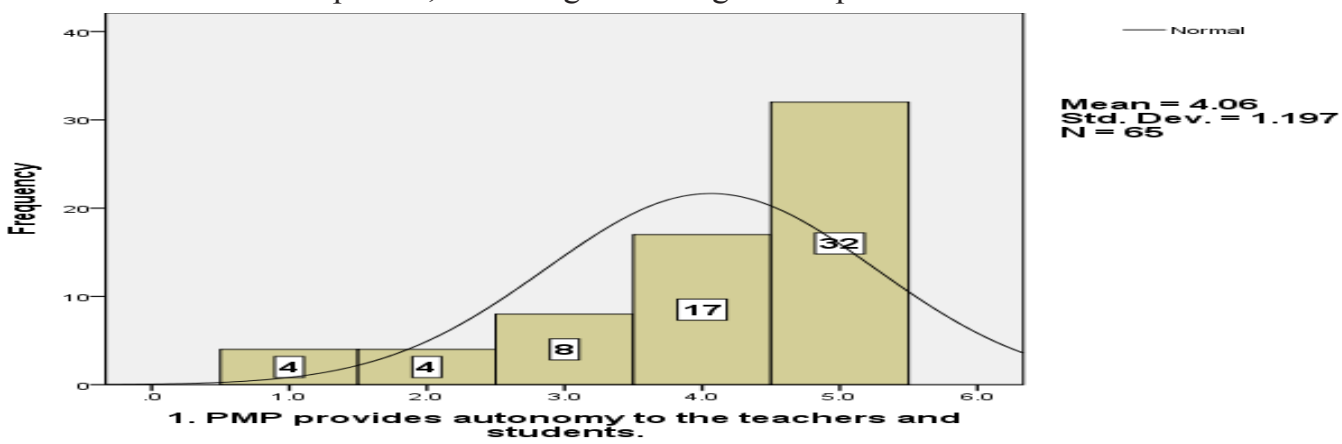

Figure 2. Respondents' agreement on autonomy attributed to PMP.

Figure 2 shows that the mean of the responses of the respondents is agree (4.06) inclined slightly towards strongly agree because the scale ranged from one to five of strongly disagree to strongly agree respectively. The distribution positively deviates from the mean score.

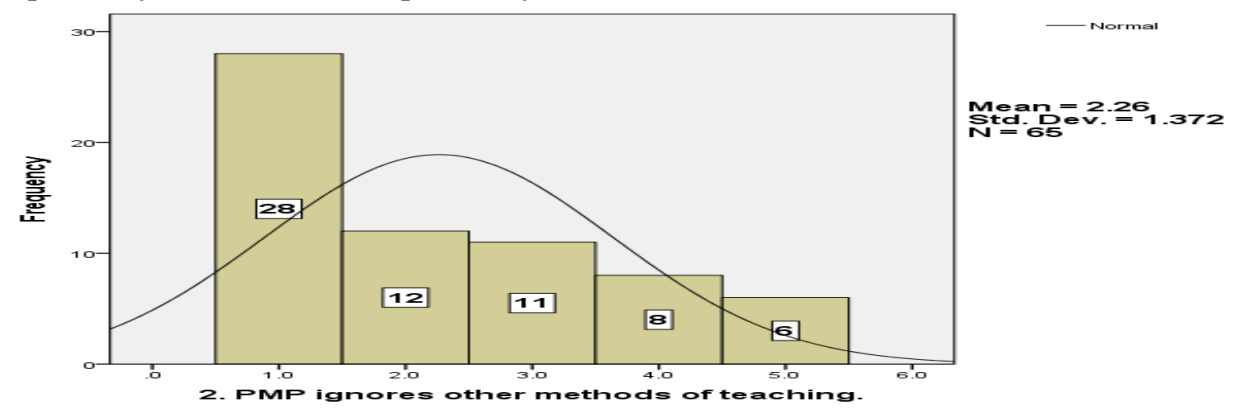

Figure 3. Respondents' agreement on treatment of PMP to other methods.

Figure 3 illustrates that the respondents did not agree that PMP ignores other teaching methods $(\mathrm{M}=2.26)$. The figure shows that the responses of the respondents positively deviated to disagreement $(\mathrm{SD}=1.372)$. 


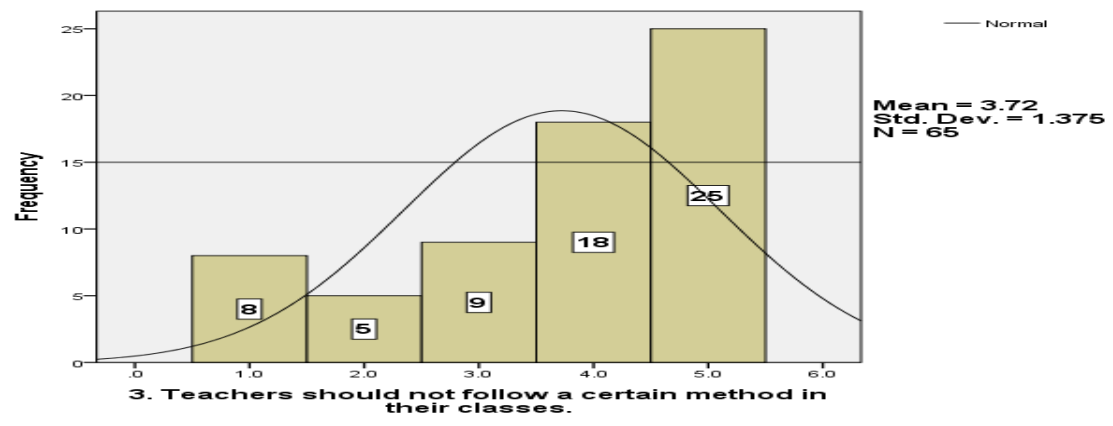

Figure 4. Respondents' agreement on selection of methods.

Figure 4 depicts that the respondents were inclined to agree $(\mathrm{M}=3.72)$ and the distribution of the responses was deviated positively $(\mathrm{SD}=1.375)$ towards an agreement. It means that they thought that the teacher should not follow one particular method while teaching different contents in different contexts.

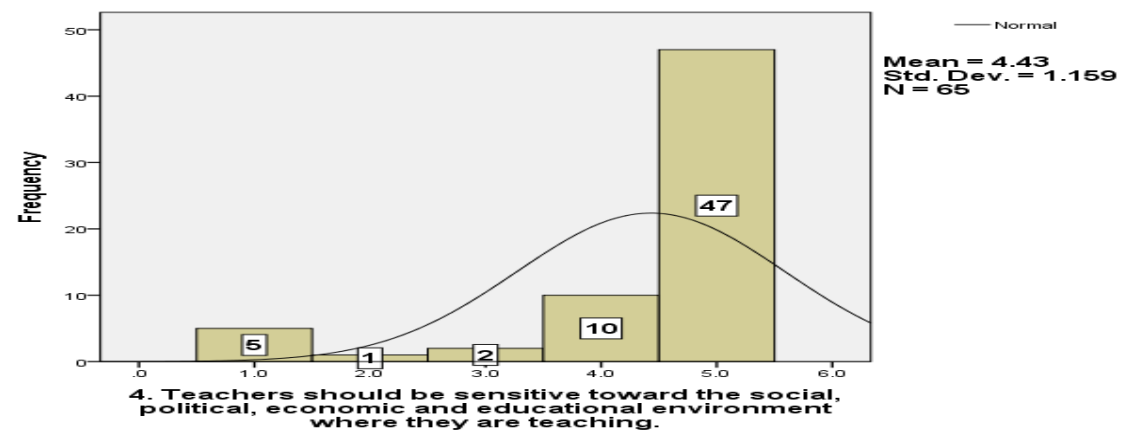

Figure 5. Respondents' agreement on teachers' sensitivity to the context.

Figure 5 shows that the respondents were more than agreed $(\mathrm{M}=4.43)$ that teachers should be sensitive towards social, political, cultural, economic, and educational contexts of the students while teaching. The responses here too were positively deviated $(\mathrm{SD}=1.159)$ towards an agreement.

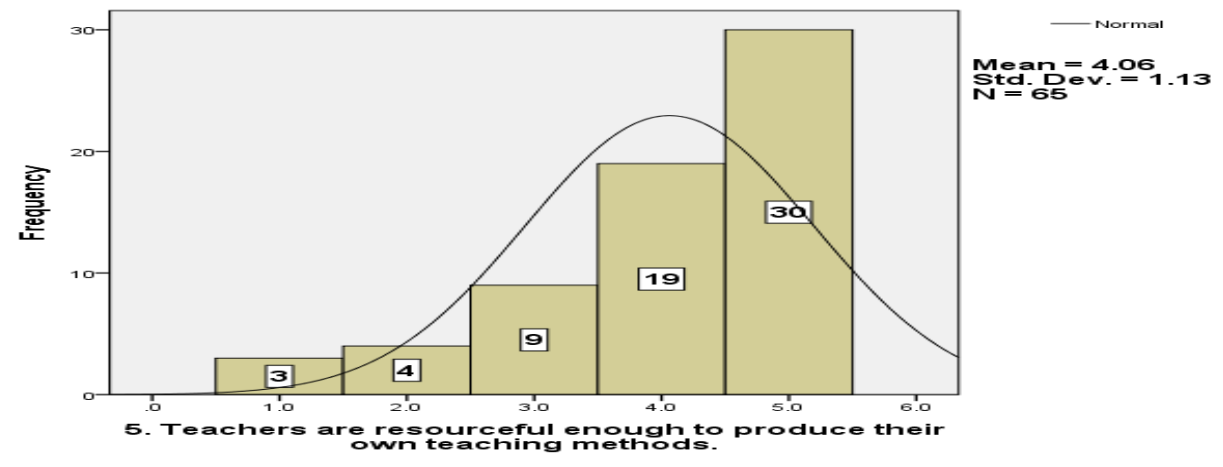

Figure 6. Respondents' agreement on potentialities of the teachers. 
Table 6 also depicts that the respondents opined in favour of teachers' resourcefulness and their potentiality to produce their own teaching methods $(M=4.06)$ and their agreement was positively deviated towards strongly agree from the mean $(\mathrm{SD}=1.13)$. Table 4 displays the overall responses of the items in Set B:

Table 4

Respondents'Agreement Towards PMP

\begin{tabular}{|c|c|c|c|c|}
\hline S.N. & Item statement & & Frequency & Percent \\
\hline \multirow[t]{5}{*}{1.} & \multirow{5}{*}{$\begin{array}{l}\text { PMP provides autonomy to the teachers } \\
\text { and students. }\end{array}$} & Strongly disagree & 4 & 6.2 \\
\hline & & Disagree & 4 & 6.2 \\
\hline & & Undecided & 8 & 12.3 \\
\hline & & Agree & 17 & 26.2 \\
\hline & & Strongly Agree & 32 & 49.2 \\
\hline \multirow[t]{5}{*}{2.} & \multirow[t]{5}{*}{ PMP ignores other methods of teaching. } & Strongly disagree & 28 & 43.1 \\
\hline & & Disagree & 12 & 18.5 \\
\hline & & Undecided & 11 & 16.9 \\
\hline & & Agree & 8 & 12.3 \\
\hline & & Strongly Agree & 6 & 9.2 \\
\hline \multirow[t]{5}{*}{3.} & \multirow{5}{*}{$\begin{array}{l}\text { Teachers should not follow a certain } \\
\text { method in their classes. }\end{array}$} & Strongly disagree & 8 & 12.3 \\
\hline & & Disagree & 5 & 7.7 \\
\hline & & Undecided & 9 & 13.8 \\
\hline & & Agree & 18 & 27.7 \\
\hline & & Strongly Agree & 25 & 38.5 \\
\hline \multirow[t]{5}{*}{4.} & \multirow{5}{*}{$\begin{array}{l}\text { Teachers should be sensitive toward } \\
\text { the social, political, economic and } \\
\text { educational environment where they are } \\
\text { teaching. }\end{array}$} & Strongly disagree & 5 & 7.7 \\
\hline & & Disagree & 1 & 1.5 \\
\hline & & Undecided & 2 & 3.1 \\
\hline & & Agree & 10 & 15.4 \\
\hline & & Strongly Agree & 47 & 72.3 \\
\hline \multirow[t]{5}{*}{5.} & \multirow{5}{*}{$\begin{array}{l}\text { Teachers are resourceful enough to } \\
\text { produce their own teaching methods. }\end{array}$} & Strongly disagree & 3 & 4.6 \\
\hline & & Disagree & 4 & 6.2 \\
\hline & & Undecided & 9 & 13.8 \\
\hline & & Agree & 19 & 29.2 \\
\hline & & Strongly Agree & 30 & 46.2 \\
\hline
\end{tabular}


Table 4 illustrates that many of the respondents $(26.2+49.2=75.4 \%)$ agreed that PMP provides autonomy to the teachers and students but some of them $(12.3 \%)$ disagreed while others $(6.2+6.2=12.4 \%)$ remained undecided. Similarly, many of them $(43.1+18.5=61.6 \%)$ did not agree that PMP ignores other methods of teaching while $16.9 \%$ remained undecided. In the same vein, more than half $(27.7+38.5=66.2 \%)$ of them agreed that teachers should not follow one particular method while teaching while $13.8 \%$ of them were neutral. Many of them $(72.3+15.4=87.7 \%)$ were agreed to the fact that teachers should be sensitive to the socio-politico-economic and educational context of the students but only $9.2 \%$ of them disagreed it. In the same way, a large number of the respondents $(29.2+46.2=75.4 \%)$ agreed that teachers are resourceful enough to produce their own teaching methods while $13.8 \%$ of them were not sure but $10.8 \%$ of them disagreed it.

Responses to each of the items were concentrated towards strongly agree except in the case of item number two which in its sense was negatively worded. It means that the respondents agreed to item number one, three, four, and five but they did not agree (item number two) that PMP ignores other methods of teaching.

More over table 5 justifies the agreement of the respondents more realistically:

Table 5

Statistics of Mean of Respondents' Agreement Towards PMP

\begin{tabular}{llllllll}
\hline & N & Mean & $\begin{array}{c}\text { Std. } \\
\text { Deviation }\end{array}$ & Skewness & \multicolumn{2}{c}{ Kurtosis } & \\
& Statistic & Statistic & Statistic & Statistic & S t d . \\
& & & & & Statistic & Std. Error \\
& & & & & & \\
\hline MeanSetB_SDA_SA & 65 & 3.7077 & .71070 & -1.146 & .297 & 1.929 & .586 \\
Valid N (listwise) & 65 & & & & & & \\
\hline
\end{tabular}

Table 5 shows the mean, standard deviation skewness and Kurtosis of the five items in Set B. The overall mean value of all the items in Set $B$ seems to be higher than neutral $(M=3.7077)$. Further, in one of the items, i.e. item number two, the respondents disagreed. So, their agreement to rest of the items is very good.

Five statement items to check against the five points Likert Scale consisting of always, often, sometimes, rarely, and never was included in Set $\mathrm{C}$. The overall responses of the respondents to these items are displayed in table 6: 
Table 6

Frequency of Respondents' Tasks as They Perceive PMP

\begin{tabular}{|c|c|c|c|c|}
\hline S.N. & Item statement & & Frequency & Percent \\
\hline \multirow[t]{5}{*}{1.} & \multirow{5}{*}{$\begin{array}{l}\text { I involve my students in workshop and } \\
\text { conferences related to the content of } \\
\text { teaching. }\end{array}$} & Always & 6 & 9.2 \\
\hline & & Often & 14 & 21.5 \\
\hline & & Sometimes & 38 & 58.5 \\
\hline & & Rarely & 7 & 10.8 \\
\hline & & Never & 0 & 0.0 \\
\hline \multirow[t]{5}{*}{2.} & \multirow{5}{*}{$\begin{array}{l}\text { I talk to my students, to learn about } \\
\text { their learning styles and preferences. }\end{array}$} & Always & 14 & 21.5 \\
\hline & & Often & 35 & 53.8 \\
\hline & & Sometimes & 15 & 23.1 \\
\hline & & Rarely & 1 & 1.5 \\
\hline & & Never & 0 & 0.0 \\
\hline \multirow[t]{5}{*}{3.} & \multirow{5}{*}{$\begin{array}{l}\text { I teach my students based on their } \\
\text { educational, social, cultural and } \\
\text { economic background. }\end{array}$} & Always & 24 & 36.9 \\
\hline & & Often & 29 & 44.6 \\
\hline & & Sometimes & 11 & 16.9 \\
\hline & & Rarely & 0 & 0.0 \\
\hline & & Never & 1 & 1.15 \\
\hline \multirow[t]{5}{*}{4.} & \multirow{5}{*}{$\begin{array}{l}\text { I select the method of teaching based } \\
\text { on socio-political and institutional } \\
\text { context. }\end{array}$} & Always & 19 & 29.2 \\
\hline & & Often & 28 & 43.1 \\
\hline & & Sometimes & 13 & 20.0 \\
\hline & & Rarely & 5 & 7.7 \\
\hline & & Never & 0 & 0.0 \\
\hline \multirow[t]{5}{*}{5.} & \multirow{5}{*}{$\begin{array}{l}\text { I think about instance of co-operation } \\
\text { and social justice in my own } \\
\text { surroundings and try to discuss them } \\
\text { in my class. }\end{array}$} & Always & 18 & 27.7 \\
\hline & & Often & 24 & 36.9 \\
\hline & & Sometimes & 22 & 33.8 \\
\hline & & Rarely & 1 & 1.5 \\
\hline & & Never & 0 & 0.0 \\
\hline
\end{tabular}

Table 6 vividly shows that many of them involve the students in workshops and conferences related to the content of teaching though only $9.2 \%$ of them always involved their students in conferences and workshops. Only $10.8 \%$ of them did it rarely while a large number of them (58.5\%) did it sometimes and $21.5 \%$ of them often did it. Similarly, they talked to their students to learn about their learning styles and preferences. Among them, $53.8 \%$ of them did it often, $23.1 \%$ sometimes did it, and $21.5 \%$ always did it but only $1.5 \%$ of them rarely did it. In the same way, many of them (44.6\%) often teach based on their students' educational, social, cultural, and economic background while $36.9 \%$ of them did it always and $16.9 \%$ of them did it sometimes but only $1.5 \%$ of them never did it. Likewise, many of them $(43.1 \%)$ often selected the method of teaching based on socio-political and institutional context while $29.2 \%$ of them always did it, $20.0 \%$ sometimes did it, and $7.7 \%$ of them rarely did it. In the like manner, $36.9 \%$ of the respondents thought about the instances of co-operation and social justice in their own surroundings and tried to discuss them in their classes while $27.7 \%$ of them always did it, $33.8 \%$ of them did it sometimes, and $1.5 \%$ of them 
rarely did it.

The replies of the respondents concentrated to the higher frequencies. They involved (often, always, and sometimes based on frequency from highest to lowest) their students in workshop and conferences related to the context, talked to their students about how they could learn, taught their students based on their context/ background, selected the contextual and apt method to address their needs, and thought about co-operation, and social justice in their own surroundings. This result showed that they were well aware of the tenants of the PMP.

Five statement items to check against the five points Likert Scale from untrue for me to true for me was included in set D where one represented untrue for me, two represented for slightly untrue for me, three represented for neutral, four represented for slightly true for me, and five represented for true for me. To analyze the responses of each item in this set, the following histogram charts of the individual items first.
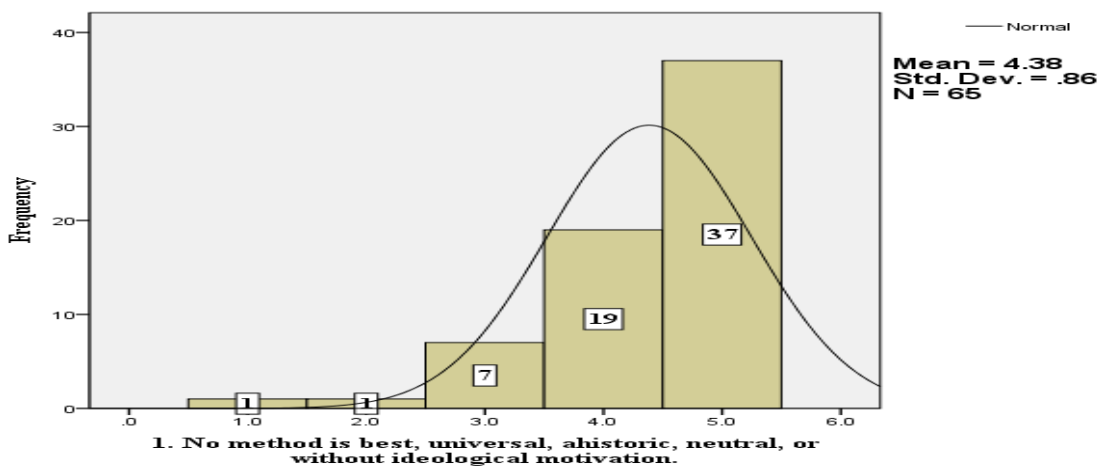

Figure 7. Respondents' view on method.

Figure 7. demonstrates that 'no method is best, universal, ahistoric, neutral or without ideological motivation' was true for them $(\mathrm{M}=4.38)$. The trueness of this item is deviated towards true $(\mathrm{SD}=.86)$ based on their responses.

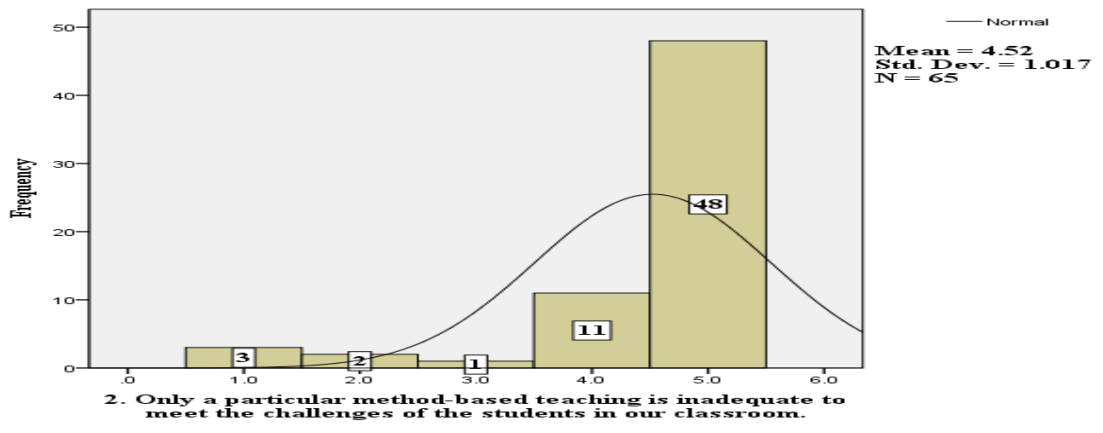

Figure 8. Respondents' view on sufficiency of one particular method.

Table 8 depicts that the respondents found it true that only particular method-based teaching is inadequate to meet the challenges of the students in their classroom $(\mathrm{M}=4.52)$. 


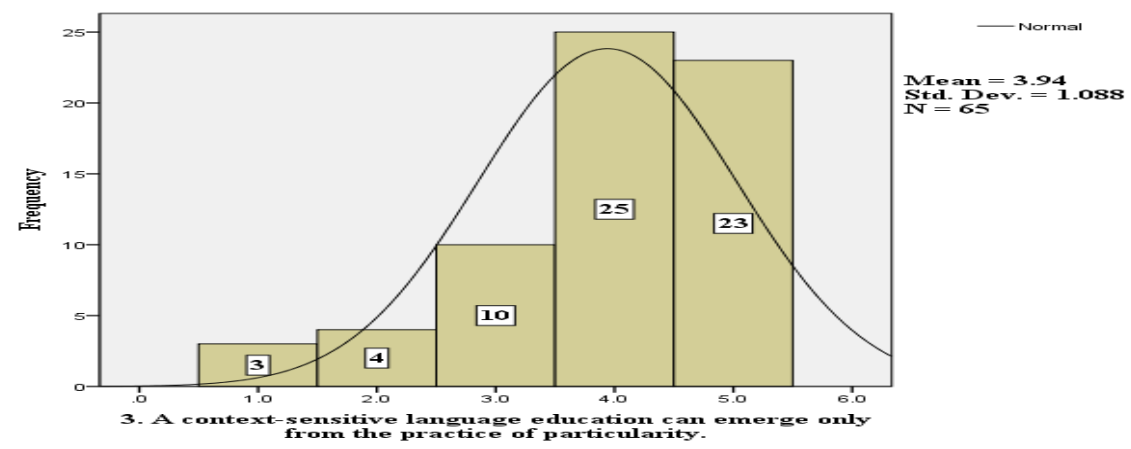

Figure 9. Respondents' view on the birth of contextual method.

Table 9 illustrates that the respondents were above the neutral inclined towards true $(\mathrm{M}=3.94)$ to the idea that a context-sensitive language education can emerge only from the practice of particularity. So, they found it true.

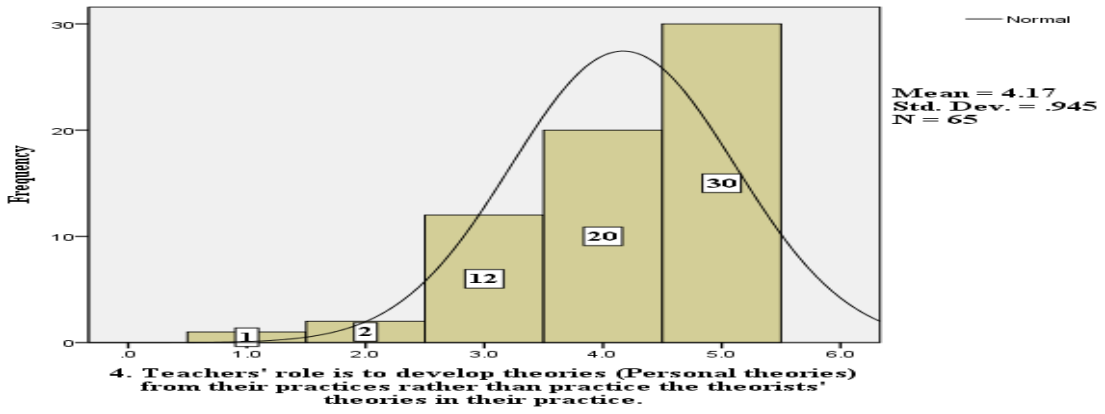

Figure 10. Respondents' view on teachers' role.

Table 10 illustrates that the respondents found it more than slightly true $(M=4.17)$ to the opinion that teachers' role is to develop their own theories from their practices rather than practising the theorists' theories alone. So, they found that teachers can also develop their theories from their practices.

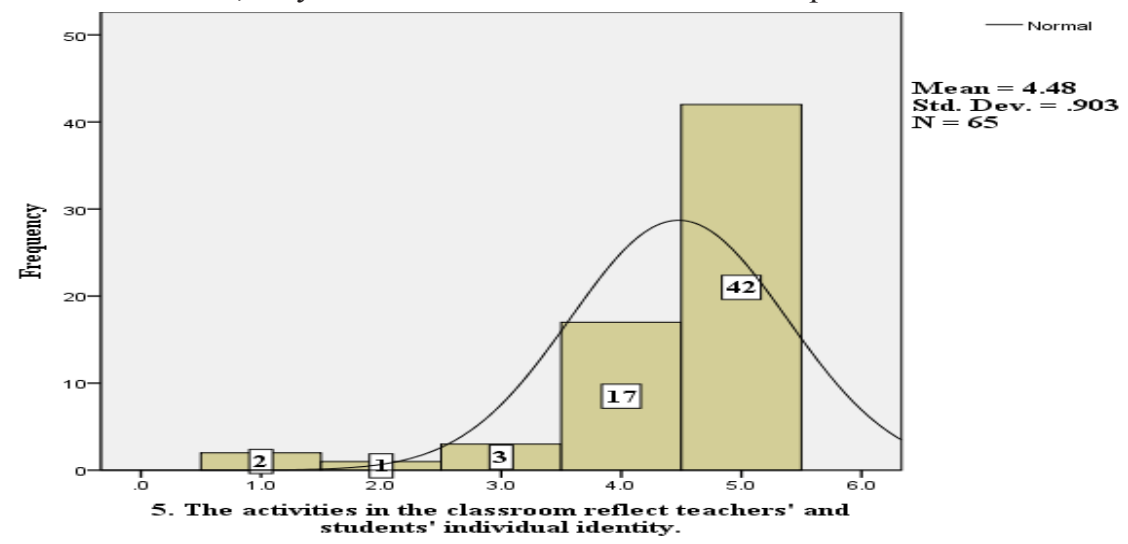

Figure 11. Respondents' view on classroom activities. 
Figure 11 shows that it was true $(M=4.48)$ that the activities in the classroom reflect the teachers' and students' individual identity. The distribution of the responses deviated to 0.903 from the mean $(\mathrm{SD}=.903)$. Many of the respondents replied it as true.

Now, the overall statistics of the responses of the items in the set can be shown through in table 7 .

Table 7

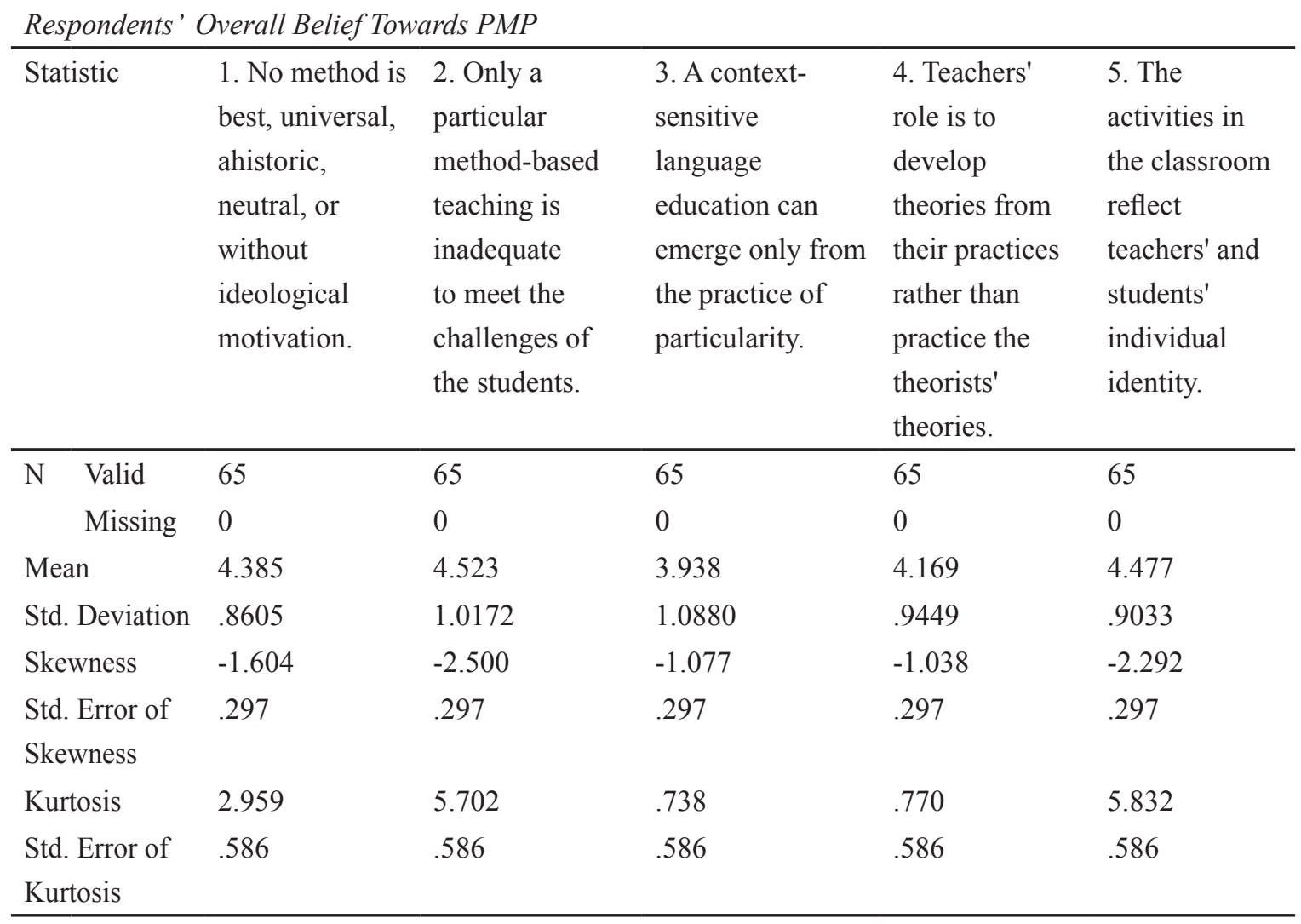

Table 7 depicts that the mean value of all the items is about four. Specifically, it is higher than four in four items and it is nearly about four $(\mathrm{M}=3.938)$ in item number three. This justifies that the respondents thought that the items were true for them. In other words, they supported the items mentioned. Similarly, the standard deviation is also not very high and the distribution is skewed towards untrue and most of the data concentrated towards slightly true for me and true for me (value 4 and 5 respectively).

Table 8 demonstrates that no method is ahistoric, neutral or any ideological motivation was true for most of them $(81.1 \%)$ while $10.8 \%$ of them were neutral. It was untrue only for three percent of them. Similarly, $90.7 \%$ of the respondents thought that one particular method is inadequate to meet all the challenges of the students in their classroom is true while only $7.8 \%$ of them found it untrue. In the same way, it was true for most of the participants (73.9\%) that context-sensitive language education can emerge only from the practice of particularity to which 15.45 of them remained neutral and $10.8 \%$ of them found 
it untrue for them. Likewise, for a large number of the participants $(77.0 \%)$ teachers' roles were to develop personal theories from their practices rather than practice others' theories was true while $18.5 \%$ of them appeared to be neutral and $4.6 \%$ of them found it untrue for them. Likewise, the activities in the classroom reflect teachers' and students' individual identity was true for $90.8 \%$ of the participants while only $4.6 \%$ of the respondents each found it neutral and untrue for them.

To show the responses of the respondents to each of the items individually, let us see the frequency table 8 .

Table 8

Respondents' Individual Belief Towards PMP

\begin{tabular}{|c|c|c|c|c|}
\hline S.N. & Item statement & & Frequency & Percent \\
\hline \multirow[t]{5}{*}{1.} & \multirow{5}{*}{$\begin{array}{l}\text { No method is best, } \\
\text { universal, ahistoric, } \\
\text { neutral, or without } \\
\text { ideological motivation. }\end{array}$} & Untrue for me & 1 & 1.5 \\
\hline & & Slightly untrue for me & 1 & 1.5 \\
\hline & & Neutral & 7 & 10.8 \\
\hline & & Slightly true for me & 19 & 29.2 \\
\hline & & True for me & 37 & 56.9 \\
\hline \multirow[t]{5}{*}{2.} & \multirow{5}{*}{$\begin{array}{l}\text { Only a particular } \\
\text { method-based teaching } \\
\text { is inadequate to meet the } \\
\text { challenges of the students } \\
\text { in our classroom. }\end{array}$} & Untrue for me & 3 & 4.6 \\
\hline & & Slightly untrue for me & 2 & 3.1 \\
\hline & & Neutral & 1 & 1.5 \\
\hline & & Slightly true for me & 11 & 16.9 \\
\hline & & True for me & 48 & 73.8 \\
\hline \multirow[t]{5}{*}{3.} & A context-sensitive & Untrue for me & 3 & 4.6 \\
\hline & \multirow{4}{*}{$\begin{array}{l}\text { language education can } \\
\text { emerge only from the } \\
\text { practice of particularity. }\end{array}$} & Slightly untrue for me & 4 & 6.2 \\
\hline & & Neutral & 10 & 15.4 \\
\hline & & Slightly true for me & 25 & 38.5 \\
\hline & & True for me & 23 & 35.4 \\
\hline \multirow[t]{5}{*}{4.} & \multirow{5}{*}{$\begin{array}{l}\text { Teachers' role is to } \\
\text { develop theories (Personal } \\
\text { theories) from their } \\
\text { practices rather than } \\
\text { practice the theorists' } \\
\text { theories in their practice. }\end{array}$} & Untrue for me & 1 & 1.5 \\
\hline & & Slightly untrue for me & 2 & 3.1 \\
\hline & & Neutral & 12 & 18.5 \\
\hline & & Slightly true for me & 20 & 30.8 \\
\hline & & True for me & 30 & 46.2 \\
\hline \multirow[t]{4}{*}{5.} & \multirow{4}{*}{$\begin{array}{l}\text { The activities in the } \\
\text { classroom reflect teachers' } \\
\text { and students' individual } \\
\text { identity. }\end{array}$} & Untrue for me & 2 & 3.1 \\
\hline & & Slightly untrue for me & 1 & 1.5 \\
\hline & & Neutral & 3 & 4.6 \\
\hline & & Slightly true for me & 17 & 26.2 \\
\hline
\end{tabular}

The mean of all the items was also calculated through the SPSS software to observe what the 
mean of the mean and standard deviation and skewness of the distribution is. The table below shows the descriptive statistics of the mean of Set D as it is was obtained through SPSS analysis:

Table 9

Statistics of Mean of Respondents'Belief Towards PMP

\begin{tabular}{llllllll}
\hline \multirow{2}{*}{$\begin{array}{l}\text { Mean Statistic } \\
\text { N }\end{array}$} & Mean & $\begin{array}{l}\text { Std. } \\
\text { Deviation }\end{array}$ & Skewness & \multicolumn{2}{c}{ Kurtosis } & \\
& Statistic & Statistic & Statistic & Statistic & Std. & Statistic & $\begin{array}{l}\text { Std. } \\
\text { Error }\end{array}$ \\
\hline MeanUntrueTrue5_1_5 & 65 & 4.2985 & .64916 & -2.195 & .297 & 9.244 & .586 \\
Valid N (listwise) & 65 & & & & & & \\
\hline
\end{tabular}

Table 9 illustrates that the mean of the mean score of the five items in the set is 4.2985 (higher than slightly true for me), though some of the scores were negatively skewed (-2.195) and the standard deviation is 0.64916 . The multiple responses, however, were centred towards slightly true or true for me.

\section{Conclusion and Implications}

Based on the result and discussion of the data collected, most of the M. Phil. pursuing scholars strictly supposed that teachers should encourage the students to take part in different contextual activities in the classroom. They opined that socio-politico-cultural and economic context of the surroundings of the students should be considered in teaching and such instances of the students should be respected fully. PMP provides autonomy to the teachers and students without ignoring any other methods in their understandings. For them, one method only cannot meet the needs of the teachers and students. The activities in the classroom that the teachers initiate are different from those suggested by any one method. Sometimes, they are uniquely utilized to solve the unique needs of the classroom.

They insisted that teachers are not just the practitioners of the theories developed by others. Instead, they can and should develop their own theories out of their practices. Teachers, for them, should encourage their students through interesting activities. So, most of them also encourage their students through the activities that interest their students when they work as teachers. They insisted that they do not follow any one particular method strictly while teaching. Rather, they try to be innovative to meet the needs of the students and the classroom setting and suggest others too. Teachers, for them, are resourceful enough to produce their own methods out of their experiences and practices. They often talked to their students to know about how they learn better. They liked to make their students creative and critical to the social phenomena and speak for social justice and social transformation. They believed that all the methods developed by now are historic and inclined to certain ideological motivation. So, they are not and cannot be neutral.

Teachers and teacher practitioners are very much aware of the recent practices and the researches in the field of teaching and learning. Professionals and potential professionals keep their eyes open and ears attentive towards the matters that influence their professional practices. Trainee teachers, teachers, and teacher trainers try using and learning about different methods of teaching during their professional and academic lives. They are the real evaluators of the methods discovered so far because they actually try 
them at their classroom. They know how to solve the problems in the classroom then any of the theorists do by learning. They actually practise the difference between saying and doing. Out of their experience and learning, they have developed their own ways of teaching the students unlike any other person suggests.

The teachers should be given choices to select any of the methods and techniques to meet their needs and address their students' needs in their own ways. The same method cannot fit equally well in each and every classroom of the world. Each teacher, each student, each classroom, the needs and necessities of the students, the surroundings, the infrastructure, the socio-politico-cultural and economic context, etc. are different in different places. So, claiming one particular method as the best is just like claiming 'one size fits all' which is not true. The contexts of the students and the teachers are best identified by the practitioners. So, the potential problems likely to occur should be left to their hands to be solved. And the teachers should not be compelled to use one particular method used elsewhere. Rather, the teachers should be left encouraged to develop their own methods to fit their situation. The era of the method has gone; it is the era of postmethods.

PMP is still waiting to be implemented in English language teaching context of Nepal. It is the turn of we practitioners to enact our ideological percepts to use and motivate using PMP in our classroom practices. This study has left many other aspects of PMP to be explored like present scenario of PMP in Nepal, methods practiced in ELT in Nepal at different levels, challenges and possibilities of the teachers in developing a context-sensitive method, etc.

\section{References}

Brown, H. D. (2001). Teaching by principles: An interactive approach to language pedagogy ( $\left.2^{\text {nd }} \mathrm{ed}.\right)$. Retrieved from https://doi.org/10.2307/3587655

Brown, H. D. (2002). English language teaching in the "Post-Method" era: Toward better diagnosis, treatment, and assessment. In J. C. Richards \& W. A. Renandya (Eds.), Methodology in language teaching: An anthology of current practice (pp. 9-18). Cambridge: Cambridge University Press.

Chen, M. (2014). Postmethod pedagogy and its influence on EFL teaching strategies. English Language Teaching, 7 (5), 17-25. https://doi.org/10.5539/elt.v7n5p17

Creswell,J.W.(2012). Educational research:Planning, conducting, and evaluating quantitative and qualitative research. In Educational Research (4 ${ }^{\text {th }}$ ed.). https://doi.org/10.1017/CBO9781107415324.004

Creswell, J. W. (2014). Research design: Qualitative, quantitative, and mixed methods approaches $\left(4^{\text {th }}\right.$ ed.). New Delhi: SAGE Publications.

Harmer, J. (2007). The practice of English language teaching (4th ed.). Edinburgh Gate: Pearson Education. Kivunja, C., \& Kuyini, A. B. (2017). Understanding and applying research paradigms in educational contexts. International Journal of Higher Education, 6(5), 26-41. Retrieved from https://doi. org/10.5430/ijhe.v6n5p26

Kumaravadivelu, B. (2001). Towards postmethod pedagogy. TESOL Quarterly, 35(4, Winter), 537-560.

Kumaravadivelu, B. (2008). Understanding language teaching: From method to postmethod. In ESL \& Applied Linguistics Professional Series. New Jersey: Lawrence Erlbaum Associates, Publishers. 
Kumravadivelu, B. (2003). Beyond methods: Macrostrategies for language teaching. London: Yale University Press.

Larshen-Freeman, D., \& Anderson, M. (2011). Techniques \& principles in language teaching (3 ${ }^{\text {rd }}$ ed.). Oxford: Oxford University Press.

Paudel, P. (2018). Teachers' perception on postmethod pedagogy in EFL classes of Nepal. Prithvi Academic Journal, 1 (1), 46-57. Retrieved from http://pncampus.edu.np/OnlineJournal/prithvi_vol_1/5.pdf

Phyak, P. (2011, January). Towards local literacy : Globalization and Nepalese ELT. ELT Choutari: Nepal's First Digital ELT Magazine. Retrieved from http://eltchoutari.com/2011/01/towards-local-literacyfor-nepalese-elt/

Richards, J. C. (2002). Theories of teaching in language teaching. In J. C. Richards \& W. A. Renandya (Eds.), Methodology in language teaching: An anthology of current practice (pp. 19-25). Cambridge: Cambridge University Press.

Richards, J. C., \& Rodgers, T. S. (2005). Approaches and methods in language teaching ( $2^{\text {nd }}$ ed.). Cambridge: Cambridge University Press.

Scholl, J. (2017). Reconceptualizing post-method pedagogy. International Journal of Language Learning and Applied Linguistics World (IJLLALW), 15(3), 96-101. Retrieved from https://www.researchgate. net/publication/318967061

Rajan Kumar Kandel is Lecturer of English Education at Tribhuvan University, Surkhet Campus (Education) where he lectures Research Methodology for Language Education, English Language Teaching Methods, and Linguistics for graduate and postgraduate students. More than a dozen articles have been published to his credit in different journals. He has also edited journals and reviewed journal articles, and facilitated different training sessions in English language teaching, academic writing, and research writings. He is interested in ICT and e-research, teacher professional development, and research-specific practices. He is Life Member of NELTA and Chairperson of NELTA Surkhet at present. 